\title{
Schoolverlaters tussen onderwijs en arbeidsmarkt 2014. Feiten en cijfers
}

Citation for published version (APA):

Meng, C. M., \& Sijbers, E. M. (2015). Schoolverlaters tussen onderwijs en arbeidsmarkt 2014. Feiten en cijfers. ROA. ROA Fact Sheets No. 001 https://doi.org/10.26481/umarof.2015001

Document status and date:

Published: 01/01/2015

DOI:

10.26481/umarof.2015001

Document Version:

Publisher's PDF, also known as Version of record

\section{Please check the document version of this publication:}

- A submitted manuscript is the version of the article upon submission and before peer-review. There can be important differences between the submitted version and the official published version of record.

People interested in the research are advised to contact the author for the final version of the publication, or visit the DOI to the publisher's website.

- The final author version and the galley proof are versions of the publication after peer review.

- The final published version features the final layout of the paper including the volume, issue and page numbers.

Link to publication

\footnotetext{
General rights rights.

- You may freely distribute the URL identifying the publication in the public portal. please follow below link for the End User Agreement:

www.umlib.nl/taverne-license

Take down policy

If you believe that this document breaches copyright please contact us at:

repository@maastrichtuniversity.nl

providing details and we will investigate your claim.
}

Copyright and moral rights for the publications made accessible in the public portal are retained by the authors and/or other copyright owners and it is a condition of accessing publications that users recognise and abide by the legal requirements associated with these

- Users may download and print one copy of any publication from the public portal for the purpose of private study or research.

- You may not further distribute the material or use it for any profit-making activity or commercial gain

If the publication is distributed under the terms of Article $25 \mathrm{fa}$ of the Dutch Copyright Act, indicated by the "Taverne" license above, 
Du Maastricht University in Learning!

Research Centre for Education and the Labour Market | ROA

\section{Schoolverlaters tussen onderwijs en arbeidsmarkt 2014 Feiten en cijfers}

\section{ROA Fact Sheet}

ROA-F-2015/1

Researchcentrum voor Onderwijs en Arbeidsmarkt | ROA Research Centre For Education and the Labour Market / ROA 


\section{Inleiding}

Het ROA verricht jaarlijks onderzoek onder schoolverlaters naar de overgang van school naar arbeidsmarkt of vervolgopleiding. Deze factsheet presenteert in het kort enkele resultaten van de meting die eind 2014 door het ROA is gehouden onder de afgestudeerden van het schooljaar 20I2-2OI3, dat wil zeggen ongeveer anderhalf jaar na het voltooien van de opleiding. Voor de volledige resultaten wordt verwezen naar het ROA-rapport Schoolverlaters tussen onderwijs en arbeidsmarkt 20I4. In totaal zijn 89.037 gediplomeerde schoolverlaters en afgestudeerden benaderd. De totale respons bedroeg 30\%.

De resultaten hebben betrekking op nagenoeg de volle breedte van het onderwijs: vmbo, mbo-bol, mbo-bbl, havo, vwo en hbo. Binnen het mbo wordt er nog onderscheid gemaakt tussen enerzijds de twee verschillende leerwegen (bol en bbl) en anderzijds binnen een leerweg tussen de 4 niveaus. De data in de factsheet zijn geaggregeerd over de onderwijssectoren, maar in de bijlage wordt ook nog een overzicht gegeven van de cijfers per opleidingsniveau gedifferentieerd naar studierichting. De resultaten voor het hbo hebben vanwege de vergelijkbaarheid alleen betrekking op de afgestudeerden van voltijd opleidingen.

De resultaten uit het onderzoek onder de gediplomeerde schoolverlaters en afgestudeerden dienen in de bredere context van de economische situatie gezien worden. Er is in de afgelopen jaren niet alleen sprake geweest van een wereldwijde financiële crisis, maar deze is tevens gevolgd door een schuldencrisis in het eurogebied. Nederland kent dan ook magere jaren na de crisis die in 2009 begon, maar er is herstel te zien richting 2017. De invloed van de economische situatie geldt niet alleen voor de indicatoren rechtstreeks gerelateerd aan de arbeidsmarktintrede (bijvoorbeeld werkloosheid of werkzekerheid) maar dit kan ook van invloed zijn op de manier waarop jongeren de afgeronde opleiding beoordelen. De lezer dient hier rekening mee te houden.

\section{Voorbereiding op de arbeidsmarkt}

Middelbare- en hogere beroepsopleidingen dienen jongeren gereed te maken voor een positie op de arbeidsmarkt. Tabel I laat het percentage gediplomeerden zien dat van mening is dat de gevolgde opleiding een (heel) goede basis bood om te starten op de arbeidsmarkt. Naast het direct startbekwaam maken, dienen opleidingen ook een basis te bieden voor het verder ontwikkelen van kennis en vaardigheden in de (onderwijs-) carrière. Tabel I laat daarom ook het percentage gediplomeerden zien dat van mening is dat de gevolgde opleiding een (heel) goede basis bood om zich verder te ontwikkelen. Van de mbo-gediplomeerden vindt in totaal $57 \%$ de opleiding een goede basis om hun vaardigheden en kennis verder te ontwikkelen, tegenover $43 \%$ die de opleiding een goede basis voor een start op de arbeidsmarkt vindt.
Binnen het mbo valt op dat de bbl-opleidingen aanmerkelijk hoger scoren als basis om te starten op de arbeidsmarkt (52\%) dan de bol-opleidingen (37\%). Dit is verklaarbaar doordat in het opleidingstraject van mbo-bbl aanmerkelijk meer werkuren bij een bedrijf zitten dan binnen het mbo-bol. Mbo-bbl opleidingen scoren echter ook hoger als basis om vaardigheden verder te ontwikkelen (6r\%) dan de bol-opleidingen (55\%). Binnen het mbo-bol scoren opleidingen op niveau 2 in het algemeen het beste op zowel de basis voor een start op de arbeidsmarkt als voor het verder ontwikkelen van kennis en vaardigheden ( $42 \%$ en $60 \%$ ). Binnen het mbo-bbl zijn het de opleidingen op niveau 3 die het hoogste op beide aspecten (6I\% en 66\%) scoren.

Van hbo-afgestudeerden vindt iets minder dan de helft de opleiding een (heel) goede basis om te starten op de arbeidsmarkt (47\%). Daarnaast vindt $63 \%$ de opleiding een (heel) goede basis om kennis en vaardigheden verder te ontwikkelen.

\section{Tabel 1}

Opleiding als voorbereiding op de arbeidsmarkt en het verder ontwikkelen van kennis en vaardigheden (\%)

\begin{tabular}{|l|c|c|}
\hline & $\begin{array}{c}\text { Starten op de } \\
\text { arbeidsmarkt } \\
\text { (Heel) goede basis (\%) }\end{array}$ & $\begin{array}{c}\text { Verder ontwikkelen kennis } \\
\text { en vaardigheden } \\
\text { (Heel) goede basis (\%) }\end{array}$ \\
\hline MBO-BOL 1 & 31 & 54 \\
\hline MBO-BOL 2 & 42 & 60 \\
\hline MBO-BOL 3 & 38 & 54 \\
\hline MBO-BOL 4 & 36 & 54 \\
\hline MBO-BBL 1 & 35 & 47 \\
\hline MBO-BBL 2 & 49 & 58 \\
\hline MBO-BBL 3 & 61 & 66 \\
\hline MBO-BBL 4 & 49 & 61 \\
\hline HBO & 47 & 63 \\
\hline
\end{tabular}

\section{Succes op de arbeidsmarkt}

Het rendement in economische termen van een opleiding hangt af van verschillende factoren bij de start in de arbeidsmarkt. Daarom is de arbeidsmarktintrede van gediplomeerden van het mbo en afgestudeerden van het hbo op verschillende indicatoren onderzocht.

Allereerst kan er bijvoorbeeld gekeken worden naar het werkloosheidsniveau onder schoolverlaters die zich aanbieden op de arbeidsmarkt (figuur I). De totale werkloosheid onder schoolverlaters op het moment van enquêteren bedraagt $8.6 \%$, wat een stijging van $\mathrm{I}, \mathrm{I} \%$-punt 
tegenover de meting in het najaar van 2013 betekent. ${ }^{I}$ De werkloosheid onder bol-gediplomeerden verschilt aanzienlijk met de werkeloosheid van de bbl-gediplomeerden. Van de schoolverlaters van mbo-bol niveau 2 is maar liefst zo'n $2 \mathrm{I} \%$ werkloos en van de schoolverlaters van mbo-bbl niveau 2 is dit $6 \%$. De werkloosheid onder mbo-gediplomeerden verschilt daarnaast aanzienlijk tussen de lagere en hogere niveaus. Terwijl voor bol niveau 4 het werkeloosheidspercentage op $9 \%$ zit, is dit bij bol niveau I $28 \%$. Ook binnen het bbl hebben gediplomeerden van bbl niveau I met II\% hogere werkeloosheidspercentages dan gediplomeerden van bbl niveau $4(4 \%)$, maar het verschil tussen deze niveaus is wel kleiner dan bij het bol. De werkloosheid onder de afgestudeerden van hbo voltijd opleiding is in vergelijking met 2013 met I\%-punt gedaald naar $7 \%$ in 2014 .

Figuur 1

Werkloosheid op enquêtemoment (\%)

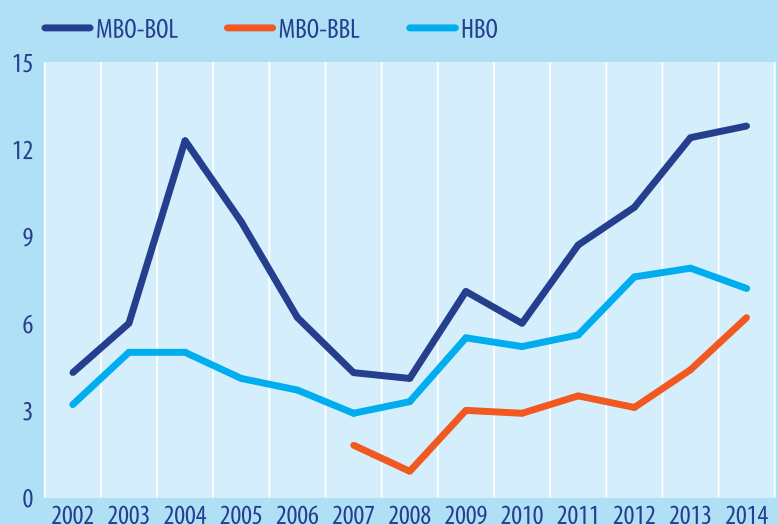

Het werkloosheidspercentage op het enquêtemoment zegt echter niet alles over hoe soepel de intrede op de arbeidsmarkt verlopen is. Daarom zijn in Figuur 2 cijfers met betrekking tot de zoekduur naar de eerste baan opgenomen. De resultaten laten allereerst verschillen zien tussen gediplomeerden van de beroepsopleidende leerweg (mbo-bol) en de beroepsbegeleidende leerweg (mbo-bbl). Gemiddeld genomen over alle vier de niveaus, kreeg $2 \mathrm{I} \%$ van de gediplomeerden van mbo-bol te maken met intredewerkloosheid tegenover $12 \%$ van de gediplomeerden van mbo-bbl. Voor de gediplomeerden met een mbo-bol diploma varieert het percentage intredewerkloosheid aanzienlijk per niveau van de opleiding. Hierbij hebben gediplomeerden van niveau I de meeste last van intredewerkloosheid (28\%, waarbij I6\%-punt zelfs langer dan 3 maanden werkloos is), gevolgd door niveau 2 (25\%, I7\%-punt langer dan 3 maanden), niveau 3 (20\%, I7\%-punt langer dan 3 maanden) en niveau 4 ( $18 \%$, I2\%-punt langer dan 3 maanden). Bij mbo-bbl heeft niveau 2 de meeste moeite met een baan te vinden ( $15 \%$, waarvan $8 \%$-punt langer dan 3 maanden), en niveau 4 de minste ( $8 \%, 3 \%$-punt langer dan 3 maanden). De resultaten laten verder zien dat de afgestudeerden van het hbo meer moeite lijken te hebben met het vinden van werk dan de gediplomeerden van het mbo. Maar liefst 35\% van de afgestudeerde hbo'ers hadden last van intredewerkloosheid, tegenover $17 \%$ van de gediplomeerde mbo'ers.

\section{Figuur 2}

Intredewerkloosheid (\%)

OMND. 1-3 MND.
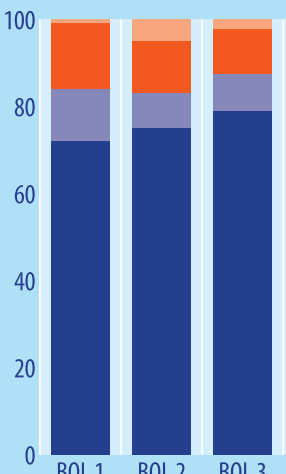

4-12 MND.

$>12$ MND.
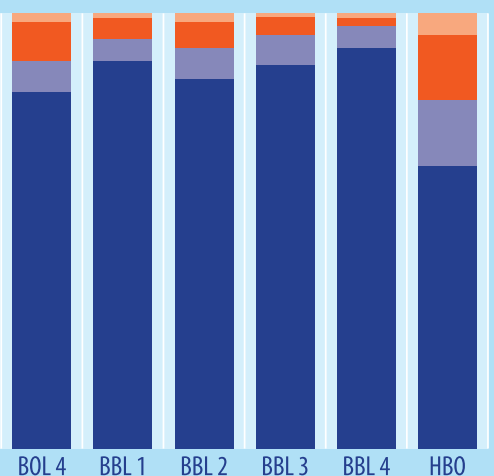

Naast werkloosheidscijfers zijn er nog enkele andere belangrijke indicatoren die een beeld geven van de aansluiting tussen onderwijs en arbeidsmarkt. Figuur 2 laat zien hoe goed het werk van schoolverlaters aansluit bij hun afgeronde opleiding wat betreft niveau en richting. Van alle werkende schoolverlaters heeft gemiddeld $67 \%$ een baan op minimaal het eigen opleidingsniveau. Dit is gedaald ten opzichte van vorig jaar, waar nog 71\% een baan op minimaal het eigen opleidingsniveau had. Het vaakst vinden de gediplomeerden van het mbo-bbl niveau 3 of 4 (beide $84 \%$ ) een baan op minstens het eigen niveau. Onder de afgestudeerden van het mbo is het $68 \%$ dat een baan op minimaal het eigen opleidingsniveau heeft, waarbij bbl-gediplomeerden vaker een baan op minstens het eigen niveau heeft (7I\%) dan bolgediplomeerden (65\%). Bij het hbo heeft gemiddeld $74 \%$ een baan op minstens het eigen niveau.

I. Vanaf dit jaar wordt in het project SchoolverlatersInformatieSysteem, dat als basis dient voor deze factsheet de werkzame beroepsbevolking benaderd volgens de definitie van de International Labour Organisation (ILO). Deze internationaal geaccepteerde norm stelt dat mensen van boven de I5 jaar die meer dan I uur werken behoren tot de werkzame beroepsbevolking. Voor de oude definitie lag deze grens op I2 uur per week. Om conclusies te kunnen trekken over ontwikkelingen die zich over verschillende jaren afspelen, zijn de cijfers van voorgaande jaren herijkt naar de internationale ILO-standaard. Daardoor kan het voorkomen dat cijfers in deze editie die betrekking hebben op metingen van eerdere jaren (2013 of eerder), niet overeenkomen met deze zelfde cijfers uit publicaties uit voorgaande jaren. 
Figuur 3

Aansluiting werk op afgeronde opleiding

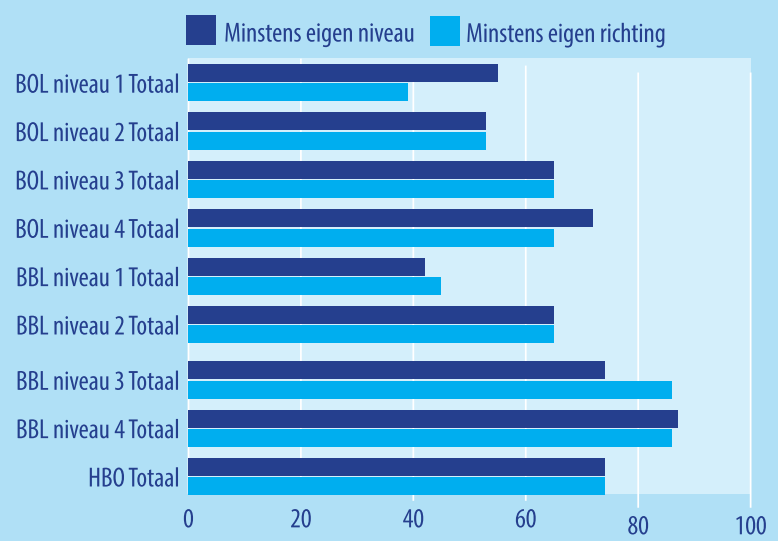

Naast het niveau van de functie is ook de richting van de functie van belang om iets te kunnen zeggen over de kwaliteit van de baan. Uit Figuur 3 blijkt dat gediplomeerde schoolverlaters van het laagste niveau binnen het mbo het minst vaak werkzaam zijn binnen het eigen beroepsdomein. Het vaakst werkzaam binnen het eigen beroepsdomein zijn gediplomeerden van mbo-bbl niveau 3 en 4 . Het valt op dat van de gediplomeerden van mbo-bol niveau 3 en 4 zo'n $70 \%$ binnen het eigen beroepsdomein werkt, terwijl dit op hetzelfde niveau bij de bbl'ers tussen de $83 \%$ (niveau 3 ) en zelfs $87 \%$ (niveau 4 ) is. De hbo'ers zitten in het midden: hiervan werkt $74 \%$ in de eigen of verwante richting.

De geënquêteerden is eveneens gevraagd wat zij vinden van de algemene aansluiting tussen de gevolgde opleiding en de huidige functie. Figuur 4 geeft weer welk deel van de werkzame schoolverlaters de aansluiting voldoende of goed vindt. Bbl-gediplomeerden zijn op alle niveaus het vaakst tevreden wat de aansluiting betreft. Een mogelijke verklaring hiervoor is de sterkere relatie tussen opleiding en arbeidsmarkt in de bbl. In het hbo is $7 \mathrm{I} \%$ van de werkende afgestudeerden van mening dat de aansluiting tussen opleiding en werk voldoende of goed is. Hoewel werkenden van het bolniveau I het minst tevreden over de aansluiting blijken te zijn, vindt van deze groep nog altijd $60 \%$ dat de aansluiting tussen opleiding en huidige functie voldoende of goed is.

Figuur 4

Aansluiting gevolgde opleiding en huidige functie (\%)

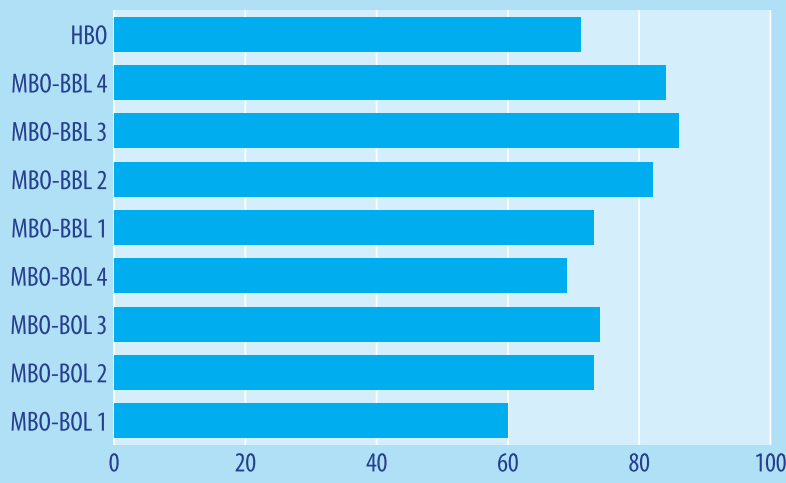

Een andere indicator voor de kwaliteit van het werk en de transitie tussen onderwijs en arbeidsmarkt is de beloning die werkzame schoolverlaters ontvangen. In Tabel 2 wordt per opleidingsniveau het gemiddelde bruto uurloon weergegeven. Het uurloon biedt een eerlijkere vergelijking dan het maandloon, omdat verschillen in het maandloon ook veroorzaakt kunnen worden door het aantal gewerkte uren. Het gemiddelde bruto uurloon neemt zoals verwacht toe met het opleidingsniveau. De enige uitzondering hierop is dat mbo-bbl 4 gediplomeerden een hoger uurloon verdienen

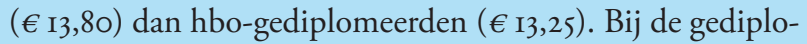
meerden van bol varieert het bruto uurloon tussen $€ 5,85$ (niveau I) en $€ 9,45$ (niveau 4 ) en bij de gediplomeerden van bbl tussen $€ 9,65$ (niveau I) en $€ \mathrm{I} 3.80$ (niveau 4).

Tabel 2

Gemiddelde bruto uurloon (€)

\begin{tabular}{|l|r|}
\hline MBO-BOL 1 & uurloon \\
\hline MBO-BOL 2 & 5,85 \\
\hline MBO-BOL 3 & 7,45 \\
\hline MBO-BOL 4 & 8,85 \\
\hline MBO-BBL 1 & 9,45 \\
\hline MBO-BBL 2 & 9,65 \\
\hline MBO-BBL 3 & 9,90 \\
\hline MBO-BBL 4 & 12,05 \\
\hline HBO & 13,80 \\
\hline
\end{tabular}

Uurloon afgerond op 5 eurocent

\section{Tevredenheid met functie}

Hoewel de kans op werk, de aansluiting tussen werk en gevolgde opleiding en het salaris belangrijke aspecten zijn van het rendement van een opleiding, is de tevredenheid van de schoolverlaters met hun werk misschien nog wel belangrijker. In Tabel 3 wordt per opleidingsniveau de tevredenheid met de huidige functie en de tevredenheid met carrièreperspectieven die de functie biedt weergegeven.

Gemiddeld is $65 \%$ van alle schoolverlaters tevreden over zijn of haar huidige functie. Het meest tevreden zijn de gediplomeerden van bbl niveau $3(72 \%)$.

Met betrekking tot de carrièreperspectieven zijn de gediplomeerden kritischer. Gemiddeld vindt 48\% dat de carrièreperspectieven die hun functie biedt goed zijn. Het zijn weer de werkenden van bbl niveau 3 die het hoogste scoren: Hier vindt $53 \%$ dat hun functie goede carrièreperspectieven heeft. Het minst tevreden zijn de gediplomeerde schoolverlaters van het laagste niveau. Zowel bij bol niveau I als bij bbl niveau I vindt slechts een derde van de respondenten $(32 \%)$ dat hun functie goede carrièreperspectieven heeft. 
Tabel 3

Tevredenheid met huidige functie en carrièreperspectieven (\%)

\begin{tabular}{|c|c|c|c|c|c|c|c|c|c|}
\hline & BOL & $\mathrm{BOL}$ & BOL & & BBL & $\begin{array}{r}\text { BBL } \\
2\end{array}$ & BBL & $\begin{array}{r}\text { BBL } \\
4\end{array}$ & HBO \\
\hline Tevreden met functie & 53 & 68 & 59 & 63 & 63 & 65 & 72 & 65 & 63 \\
\hline $\begin{array}{l}\text { Goede } \\
\text { carrièreperspectieven }\end{array}$ & 32 & 47 & 44 & 44 & 32 & 50 & 53 & 45 & 51 \\
\hline
\end{tabular}

\section{Doorstroom naar vervolgopleiding}

$\mathrm{Na}$ het behalen van hun diploma kunnen jongeren er voor kiezen om een vervolg te geven aan hun onderwijsloopbaan in plaats van zich direct aan te bieden op de arbeidsmarkt. In Figuur 5 staat een overzicht van de kwalificerende vervolgtrajecten van de gediplomeerde schoolverlaters uit het onderzoek. De figuur vermeldt per onderwijssoort het percentage van de gediplomeerde schoolverlaters dat sinds het moment van afstuderen naar een bepaald kwalificerend vervolgtraject is gegaan evenals het percentage dat niet voor een kwalificerend vervolgtraject heeft gekozen. Voor de duidelijkheid zijn in de figuur de bol- en bblniveaus samengevoegd en worden alleen vervolgtrajecten met een aandeel van minstens $5 \%$ weergegeven. Van het avo stroomt het overgrote deel door naar een vervolgopleiding. Van de totale groep havo-respondenten is $79 \%$ doorgestroomd naar een hbo-opleiding. Van de vwo'ers is $17 \%$ naar het hbo gegaan en heeft het merendeel $(76 \%)$ voor een studie in het wo gekozen. Van de gediplomeerde vmbo-respondenten gaat $2 \%$ niet verder met een vervolgopleiding. De doorstroom van vmbo naar havo is volgens de figuur een kleine $8 \%$. Vanuit de havo gaat $13 \%$ niet verder met een kwalificerend vervolgtraject, en vanuit het vwo $6 \%$. Dit betreft vaak jongeren die een tussenjaar nemen.

\section{Figuur 5}

Kwalificerende vervolgtrajecten na het verlaten studie

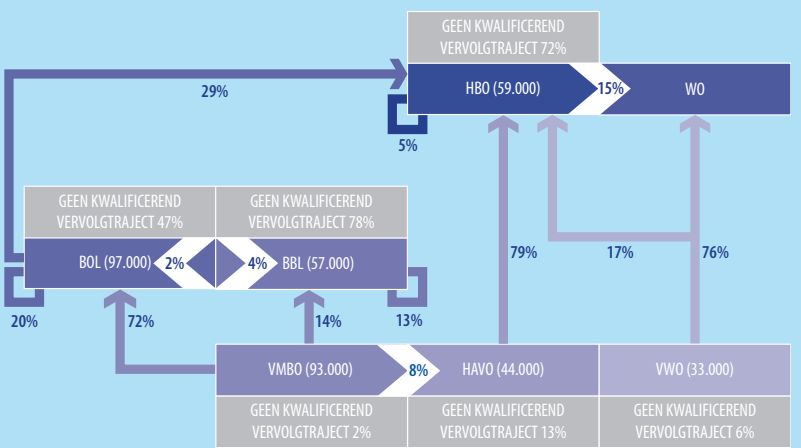

Aan de schoolverlaters die doorstromen naar een vervolgopleiding is gevraagd hoe zij de aansluiting beoordelen tussen de voltooide opleiding en de vervolgopleiding. Figuur 6 geeft weer welk deel van de verder lerende schoolverlaters deze aansluiting voldoende of goed vindt. De overgrote meerderheid van de doorstromers naar een vervolgopleiding is van mening dat de aansluiting tussen de eerder gevolgde opleiding en de vervolgopleiding voldoende tot goed is.

Bij het mbo-bol valt op dat het oordeel over een goede aansluiting duidelijk afneemt naarmate het gevolgde onderwijsniveau toeneemt. Is $83 \%$ van de gediplomeerden van het mbo-bol niveau I tevreden over de aansluiting, onder de gediplomeerden van het hoogste mbo-bol niveau is het gemiddeld 'slechts' $55 \%$. Dit betekent natuurlijk tegelijkertijd dat $45 \%$ de aansluiting matig of slecht vindt. Hierbij dient rekening mee gehouden te worden dat voor de gediplomeerden van de lagere mbo-bol opleidingen de doorstroom naar een vervolgopleiding in de regel binnen het mbo plaatsvindt, terwijl doorleren voor de gediplomeerden van het mbo niveau 4 in de regel een overstap naar het hbo betekent.

Behalve de aansluiting, is de uitval van een vervolgopleiding tevens een maatstaf voor de kwaliteit. Figuur 7 laat zien welk deel van de jongeren de vervolgopleiding voortijdig verlaat zonder aan een nieuwe opleiding te beginnen (netto uitval) en welk deel van vervolgopleiding gewisseld is. In totaal geeft $9 \%$ van de respondenten aan dat ze gestopt zijn met de vervolgopleiding die ze kozen. Dit bestaat uit 6\%-punt die aangeeft van studie gewisseld te zijn, en uit $3 \%$-punt die gestopt zijn zonder aan een andere studie te beginnen. Van de gediplomeerden van het mbo-bol niveau 4 stoppen de meeste met hun vervolgstudie: In totaal $17 \%$ geeft aan met de vervolgstudie gestopt te zijn.

Figuur 6

Aansluiting voltooide opleiding en vervolgopleiding (\%)

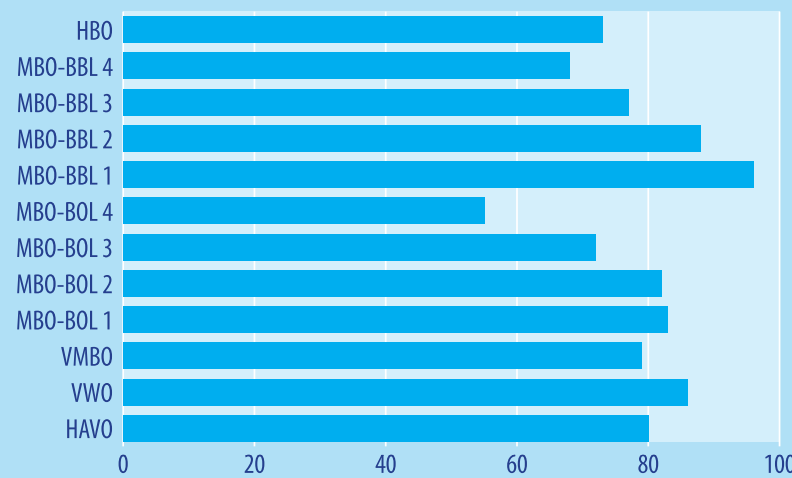

Het valt meteen op dat het mbo-bbl een groot contrast is op het mbo-bol. In totaal verlaat $\mathrm{I} 3 \%$ van de mbo-bol gediplomeerden voortijdig hun vervolgopleiding, tegenover $4 \%$ bij het mbo-bbl. Daarnaast wisselt bij het mbo-bol 6\% van studie, maar komt dit bij het mbo-bbl nagenoeg niet voor. 


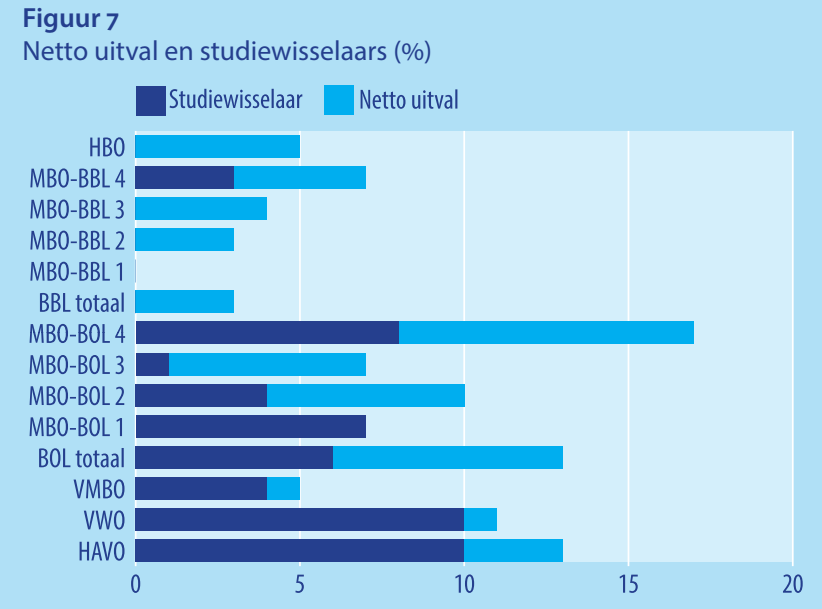

\section{Tevredenheid opleiding}

Op basis van verschillende indicatoren is de tevredenheid van de schoolverlaters over de door hun gevolgde opleiding gemeten. Hierbij is zowel naar inhoudelijke onderwijszaken (zoals de inhoud van de vakken, manier van lesgeven) als naar meer materiële en praktische aspecten (zoals voorzieningen) gekeken.

Voor de meerderheid van de aspecten geldt dat schoolverlaters van het havo/vwo positiever zijn dan schoolverlaters van het vmbo of mbo. Voornamelijk de sfeer op school wordt erg hoog beoordeeld: Bijna $80 \%$ van de gediplomeerden van het havo/vwo was (zeer) tevreden over de sfeer op school. De gediplomeerden van het mbo scoren op de meerderheid van de aspecten de laagste tevredenheidscijfers. Zowel op materiële voorzieningen (42\%), huisvesting ( $52 \%)$, de kwaliteit van de examens $(47 \%)$, de manier van examineren $(47 \%)$, de inhoud van de vakken $(40 \%)$, de manier waarop de leraren les gaven (48\%), studievoorlichting $(35 \%)$ en de sfeer op school ( $57 \%)$ word het mbo het slechtst beoordeeld. Op de hoeveelheid praktijk haalt het mbo de hoogste score, waarbij $5 \mathrm{I} \%$ van de mbo-gediplomeerden tevreden is over de hoeveelheid praktijk in de opleiding. Echter, gezien dat het mbo een beroepsgerichte opleiding is, wil dit zeggen dat alsnog de helft niet tevreden is over de hoeveelheid praktijk van deze opleiding. Bij het mbo-bbl zijn ze marginaal tevredener dan bij het mbo-bol, waarbij $49 \%$ van de bol-gediplomeerden tevreden is over de hoeveelheid praktijk in hun opleiding tegenover $53 \%$ van de bbl-gediplomeerden.
Als samenvattend oordeel is de gediplomeerden gevraagd of ze achteraf gezien opnieuw voor dezelfde opleiding zouden kiezen (zie Tabel 4). Van alle gediplomeerde schoolverlaters zou ongeveer $80 \%$ dezelfde opleiding weer opnieuw kiezen. Dit percentage laat zien dat de overgrote meerderheid van de respondenten nog steeds achter de door hun gemaakte studiekeuze staan. Het avo scoort hierbij het hoogst, waar maar liefst $97 \%$ dezelfde opleiding opnieuw zou kiezen. De hoeveelheid gediplomeerden die achteraf bezien een andere opleiding zou kiezen is het hoogst bij het mbo-bol. Hier zou 23\% (mbo-bol niveau 4) à 32\% (mbobol niveau I) een andere opleiding kiezen als ze de keuze opnieuw moesten maken. Bij de mbo-bbl opleidingen zou I6\% (mbo-bbl niveau 4) tot $24 \%$ (mbo-bbl niveau I) een andere keuze maken. Voor gediplomeerde hbo'ers zou $77 \%$ dezelfde opleiding achteraf bezien opnieuw kiezen.

Tabel 4

Tevredenheid achteraf (\%)

\begin{tabular}{|l|r|r|}
\hline & \multicolumn{2}{|c|}{$\begin{array}{c}\text { Opleidingskeuze } \\
\text { Dezelfde opleiding }\end{array}$} \\
\hline AV0 & 97 & Andere opleiding \\
\hline VMBO & 88 & 12 \\
\hline MBO-BOL 1 & & \\
\hline MBO-BOL 2 & 68 & 32 \\
\hline MBO-BOL 3 & 73 & 27 \\
\hline MBO-BOL 4 & 74 & 26 \\
\hline MBO-BBL 1 & 77 & 23 \\
\hline MBO-BBL 2 & & \\
\hline MBO-BBL 3 & 76 & 24 \\
\hline MBO-BBL 4 & 84 & 16 \\
\hline HBO & 82 & 18 \\
\hline
\end{tabular}




\section{Algemeen}

\begin{tabular}{|c|c|c|c|}
\hline & $\begin{array}{l}\text { Opleiding goede basis om te starten op } \\
\text { arbeidsmarkt (\%) }\end{array}$ & $\begin{array}{l}\text { Opleiding goede basis voor verder } \\
\text { ontwikkelen van kennis en vaardigheden (\%) }\end{array}$ & $\begin{array}{l}\text { Opleiding achteraf } \\
\text { opnieuw kiezen (\%) }\end{array}$ \\
\hline VMBO & 27 & 57 & 88 \\
\hline VMBO theoretische leerweg & 25 & 56 & 88 \\
\hline VMBO landbouw & 24 & 55 & 89 \\
\hline VMBO techniek & 39 & 63 & 87 \\
\hline VMBO economie & 32 & 54 & 87 \\
\hline VMB0 gezondheidszorg & 23 & 60 & 87 \\
\hline VMBO intersectoraal & 24 & 55 & 86 \\
\hline MBO & 43 & 57 & 78 \\
\hline BOL & 37 & 55 & 75 \\
\hline BOL 1 & 31 & 54 & 68 \\
\hline BOL 2 & 42 & 60 & 73 \\
\hline BOL 2 landbouw & 43 & 60 & 68 \\
\hline BOL 2 techniek & 38 & 54 & 72 \\
\hline BOL 2 economie & 47 & 63 & 71 \\
\hline BOL 2 gezondheidszorg & 38 & 61 & 75 \\
\hline BOL 3 & 38 & 54 & 74 \\
\hline BOL 3 landbouw & 34 & 51 & 65 \\
\hline BOL 3 techniek & 47 & 48 & 77 \\
\hline BOL 3 economie & 36 & 50 & 73 \\
\hline BOL 3 gezondheidszorg & 49 & 62 & 77 \\
\hline BOL 3 gedrag en maatschappij & 28 & 56 & 72 \\
\hline BOL 4 & 36 & 54 & 77 \\
\hline BOL 4 landbouw & 38 & 51 & 74 \\
\hline BOL 4 techniek & 45 & 58 & 76 \\
\hline BOL 4 economie & 32 & 52 & 75 \\
\hline BOL 4 gezondheidszorg & 44 & 61 & 83 \\
\hline BOL 4 gedrag en maatschappij & 27 & 51 & 75 \\
\hline BBL & 52 & 61 & 83 \\
\hline BBL 1 & 35 & 47 & 76 \\
\hline BBL 2 & 49 & 58 & 84 \\
\hline BBL 2 landbouw & 47 & 58 & 89 \\
\hline BBL 2 techniek & 51 & 56 & 87 \\
\hline BBL 2 economie & 47 & 62 & 77 \\
\hline BBL 2 gezondheidszorg & 49 & 63 & 81 \\
\hline BBL 3 & 61 & 66 & 82 \\
\hline BBL 3 landbouw & 59 & 66 & 83 \\
\hline BBL 3 techniek & 67 & 68 & 81 \\
\hline BBL 3 economie & 43 & 50 & 74 \\
\hline BBL 3 gezondheidszorg & 74 & 77 & 86 \\
\hline BBL 3 gedrag en maatschappij & 51 & 78 & 92 \\
\hline
\end{tabular}




\section{Algemeen}

\begin{tabular}{|c|c|c|c|}
\hline & $\begin{array}{l}\text { Opleiding goede basis om te starten op } \\
\text { arbeidsmarkt (\%) }\end{array}$ & $\begin{array}{l}\text { Opleiding goede basis voor verder } \\
\text { ontwikkelen van kennis en vaardigheden (\%) }\end{array}$ & $\begin{array}{l}\text { Opleiding achteraf } \\
\text { opnieuw kiezen (\%) }\end{array}$ \\
\hline BBL 4 & 49 & 61 & 85 \\
\hline BBL 4 landbouw & 48 & 64 & 85 \\
\hline BBL 4 techniek & 38 & 62 & 84 \\
\hline BBL 4 economie & 37 & 46 & 81 \\
\hline BBL 4 gezondheidszorg & 65 & 70 & 89 \\
\hline BBL 4 gedrag en maatschappij & 47 & 59 & 75 \\
\hline HBO & 47 & 63 & 77 \\
\hline HBO landbouw & 55 & 67 & 75 \\
\hline HBO techniek & 59 & 68 & 84 \\
\hline HBO economie & 46 & 61 & 70 \\
\hline HBO gezondheidszorg & 50 & 68 & 84 \\
\hline HBO gedrag en maatschappij & 35 & 60 & 72 \\
\hline HBO onderwijs & 50 & 58 & 86 \\
\hline HBO taal en cultuur & 29 & 70 & 82 \\
\hline Totaal & 39 & 58 & 84 \\
\hline
\end{tabular}

Bron: ROA (SIS) 


\section{Vervolgopleiding}

\begin{tabular}{|c|c|c|c|}
\hline & $\begin{array}{l}\text { Aansluiting } \\
\text { redelijk/goed (\%) }\end{array}$ & $\begin{array}{c}\text { Netto uitval } \\
\text { in vervolgopleiding (\%) }\end{array}$ & $\begin{array}{c}\text { Studiewisselaar } \\
\text { in vervolgopleiding (\%) }\end{array}$ \\
\hline HAVO/VWO & 83 & 2 & 10 \\
\hline HAVO & 80 & 3 & 10 \\
\hline vwo & 86 & 1 & 10 \\
\hline VMBO & 79 & 1 & 4 \\
\hline VMBO theoretische leerweg & 79 & 1 & 5 \\
\hline VMBO landbouw & 75 & 1 & 5 \\
\hline VMBO techniek & 84 & 2 & 1 \\
\hline VMBO economie & 84 & 0 & 5 \\
\hline VMBO gezondheidszorg & 75 & 1 & 3 \\
\hline VMBO intersectoraal & 79 & 1 & 8 \\
\hline MBO & 70 & 6 & 5 \\
\hline BOL & 66 & 7 & 6 \\
\hline BOL 1 & 83 & 1 & 7 \\
\hline BOL 2 & 82 & 6 & 4 \\
\hline BOL 2 landbouw & 82 & 4 & 5 \\
\hline BOL 2 techniek & 85 & 4 & 6 \\
\hline BOL 2 economie & 79 & 4 & 5 \\
\hline BOL 2 gezondheidszorg & 85 & 8 & 3 \\
\hline BOL 3 & 72 & 6 & 1 \\
\hline BOL 3 landbouw & 76 & 10 & 0 \\
\hline BOL 3 techniek & 87 & 2 & 0 \\
\hline BOL 3 economie & 68 & 6 & 1 \\
\hline BOL 3 gezondheidszorg & 72 & 4 & 2 \\
\hline BOL 3 gedrag en maatschappij & 75 & 6 & 1 \\
\hline BOL 4 & 55 & 9 & 8 \\
\hline BOL 4 landbouw & 53 & 5 & 4 \\
\hline BOL 4 techniek & 50 & 10 & 6 \\
\hline BOL 4 economie & 58 & 8 & 9 \\
\hline BOL 4 gezondheidszorg & 61 & 7 & 8 \\
\hline BOL 4 gedrag en maatschappij & 52 & 9 & 10 \\
\hline BBL & 83 & 4 & 0 \\
\hline BBL 1 & 96 & 0 & 0 \\
\hline BBL 2 & 88 & 3 & 0 \\
\hline BBL 3 & 77 & 4 & 0 \\
\hline BBL 4 & 68 & 4 & 3 \\
\hline
\end{tabular}




\section{Vervolgopleiding}

\begin{tabular}{|c|c|c|c|}
\hline & redelijk/goed (\%) & in vervolgopleiding (\%) & in vervolgopleiding (\%) \\
\hline HBO & 73 & 5 & 0 \\
\hline HBO landbouw & 73 & 3 & 0 \\
\hline HBO techniek & 67 & 8 & 1 \\
\hline HBO economie & 72 & 4 & 1 \\
\hline HBO gezondheidszorg & 79 & 3 & 0 \\
\hline HBO gedrag en maatschappij & 73 & 6 & 0 \\
\hline HBO onderwijs & 83 & 4 & 0 \\
\hline HBO taal en cultuur & - & 6 & 0 \\
\hline Totaal & 77 & 3 & 6 \\
\hline
\end{tabular}

Bron: ROA (SIS) 


\title{
Arbeidsmarkt
}

$\begin{array}{cccccc}\text { Minimaal op eigen } & \text { Eigen/verwante } & \text { Aansluiting } & \text { Werkloos } & \text { Intrede werkloosheid } & \text { Bruto uurloon } \\ \text { niveau (\%) } & \text { richting (\%) } & \text { voldoende/goed (\%) } & (\%) & >3 \text { mnd. (\%) } & \text { (euro) }\end{array}$

\begin{tabular}{|c|c|c|c|c|c|c|}
\hline MBO & 68 & 69 & 77 & 10 & 10 & 10,16 \\
\hline BOL & 65 & 61 & 71 & 13 & 13 & 8,82 \\
\hline BOL 1 & 56 & 40 & 60 & 28 & 16 & 5,83 \\
\hline BOL 2 & 54 & 53 & 73 & 21 & 17 & 7,46 \\
\hline BOL 2 landbouw & 77 & 65 & 73 & 21 & 15 & 6,66 \\
\hline BOL 2 techniek & 61 & 47 & 70 & 26 & 14 & 7,41 \\
\hline BOL 2 economie & 59 & 46 & 67 & 18 & 19 & 7,31 \\
\hline BOL 2 gezondheidszorg & 61 & 64 & 79 & 20 & 16 & 7,78 \\
\hline
\end{tabular}

BOL 3

BOL 3 landbouw

BOL 3 techniek

BOL 3 economie

BOL 3 gezondheidszorg

BOL 3 gedrag en maatschappij

65
55
63
58
72
71

64
51
64
50
81
73

74
62
69
72
85
70

$\begin{array}{ccc}11 & 12 & 8,84 \\ 16 & 14 & 7,38 \\ 13 & 20 & 10,32 \\ 14 & 11 & 8,00 \\ 5 & 11 & 9,78 \\ 8 & 14 & 8,88\end{array}$

BOL 4
BOL 4 landbouw
BOL 4 techniek
BOL 4 economie
BOL 4 gezondheidszorg
BOL 4 gedrag en maatschappij

72
69
72
65
84
66

64
63
69
52
81
55

\section{BBL}

\begin{abstract}
71
\end{abstract}
75

83

73

82
84
82
75
87

$46 \quad 44$

$44 \quad 73$

BBL 2

BBL 2 landbouw

65
60
66
60
71

66
57
65
67
72

\begin{tabular}{l} 
BBL 3 \\
BBL 3 landbouw \\
BBL 3 techniek \\
BBL 3 economie \\
BBL 3 gezondheidszorg \\
\hline$B B L 3$ gedrag en maatschappij
\end{tabular}

$74 \quad 86$

86

$\begin{array}{cccc}86 & 6 & 6 & 12,04 \\ 86 & 3 & 2 & 11,33 \\ 84 & 4 & 6 & 12,33 \\ 78 & 12 & 9 & 10,19 \\ 92 & 3 & 0 & 12,77 \\ 91 & 7 & 6 & 14,22 \\ 84 & & & \\ 81 & 4 & 3 & 13,79 \\ 81 & 6 & 6 & 13,04 \\ 87 & 2 & 4 & 14,46 \\ 86 & 5 & 4 & 12,20 \\ - & 2 & 1 & 14,32 \\ & 16 & 6 & -\end{array}$

$\begin{array}{ll}72 & 83 \\ 74 & 85\end{array}$

$54 \quad 75$

$83 \quad 94$

BBL 3 gedrag en maatschappij

$88 \quad 92$

BBL 4

BBL 4 landbouw

BBL 4 techniek

$\begin{array}{ll}87 & 86 \\ 78 & 73 \\ 79 & 86 \\ 78 & 72 \\ 87 & 98 \\ - & -\end{array}$

BBL 4 economie

BBL 4 gezondheidszorg

BBL 4 gedrag en maatschappij 


\section{Arbeidsmarkt}

$\begin{array}{cccccc}\begin{array}{c}\text { Minimaal op eigen } \\ \text { niveau (\%) }\end{array} & \begin{array}{c}\text { Eigen/verwante } \\ \text { richting (\%) }\end{array} & \begin{array}{c}\text { Aansluiting } \\ \text { voldoende/goed (\%) }\end{array} & \begin{array}{c}\text { Werkloos } \\ (\%)\end{array} & \begin{array}{c}\text { Intrede werkloosheid } \\ >3 \text { mnd. (\%) }\end{array} & \begin{array}{c}\text { Bruto uurloon } \\ \text { (euro) }\end{array}\end{array}$

74
73
84
75
79
49
87
64

$\begin{array}{ll}74 & 71 \\ 70 & 68 \\ 82 & 77 \\ 64 & 66 \\ 89 & 82 \\ 71 & 64 \\ 88 & 81 \\ 64 & 68\end{array}$

$7 \quad 20$

$20 \quad 13,26$

HBO landbouw

HBO techniek

$8 \quad 19$

$\mathrm{HBO}$ economie

$\mathrm{HBO}$ gezondheidszorg

$\mathrm{HBO}$ gedrag en maatschappij

$\mathrm{HBO}$ onderwijs

$\mathrm{HBO}$ taal en cultuur

70

70

75

19

17

13,09

Totaal

Bron: ROA (SIS)

8

14,11

$19 \quad 14,81$

$27 \quad 12,77$

$19-12,77$

$18 \quad 10,10$




\section{Trendcijfers werkloosheid}

\begin{tabular}{|c|c|c|c|c|c|c|c|c|c|c|c|c|}
\hline & 2003 & 2004 & 2005 & 2006 & 2007 & 2008 & 2009 & 2010 & 2011 & 2012 & 2013 & 2014 \\
\hline MBO-BOL 1/2 & 14 & 23 & 19 & 11 & 8 & 8 & 12 & 12 & 16 & 16 & 21 & 22 \\
\hline MBO-BOL $3 / 4$ & 3 & 8 & 6 & 5 & 2 & 3 & 5 & 4 & 6 & 8 & 10 & 10 \\
\hline MBO-BBL 1/2 & 4 & 5 & 6 & 3 & 3 & 1 & 4 & 4 & 5 & 4 & 6 & 7 \\
\hline MBO-BBL $3 / 4$ & 2 & 4 & 2 & 2 & 1 & 1 & 2 & 2 & 2 & 2 & 3 & 5 \\
\hline HBO & 5 & 5 & 4 & 4 & 3 & 3 & 5 & 5 & 6 & 8 & 8 & 7 \\
\hline
\end{tabular}

-: Niet beschikbaar

Toelichting: Het jaartal heeft betrekking op het meetjaar. In 2012 is het cohort 2010-2011 bevraagd.

Opmerking: In de metingen van $2000 \mathrm{t} / \mathrm{m} 2002$ betreft het schoolverlaters van MAVO/VBO. Vanaf de meting 2003 betreft het schoolverlaters van VMBO. 


\section{Colofon}

(C) Researchcentrum voor Onderwijs en Arbeidsmarkt (ROA). Niets uit deze uitgave mag op enige manier worden verveelvoudigd zonder voorafgaande schriftelijke toestemming van de directeur van het ROA.

Researchcentrum voor Onderwijs en Arbeidsmarkt Maastricht University

School of Business and Economics

secretary-roa-sbe@maastrichtuniversity.nl

www.roa.nl

\section{Vormgeving}

ROA secretariaat, Maastricht

juli 2015 
Researchcentrum voor Onderwijs en Arbeidsmarkt

Postbus 616

6200 MD Maastricht

$\mathrm{T}+31433883647$

F +31 433884914

secretary-roa-sbe@maastrichtuniversity.nl

www.roa.nl

Maastricht University

School of Business and Economics 